\title{
Writing from un lugar negro: A call towards healing fantasmas chingadas
}

\author{
Angie Mejia ${ }^{1}$
}

In this article, I weave personal recollections as a sexual abuse survivor with a selected review of the empirical literature on Latinas and sexual violence in order to begin a discussion towards the need to go beyond the "sharing our experiences" as a healing technique. As daughters of Malinche our project should be devoted to investing our energies into the de- and reconstruction of those discourses that have made us into objects of sexual prey and shame. In doing so, we can truly transform our communities ideas about mujeres and gender. [Article copies available for a fee from The Transformative Studies Institute. E-mail address: journal@transformativestudies.org Website: http://www.transformativestudies.org (C2011 by The Transformative Studies Institute. All rights reserved.]

KEYWORDS: Sexual Violence, Child Sexual Abuse, Latina Feminisms, Latinas and Mental Health Issues.

Audre Lorde encourages us to write from a dark place "within where hidden and growing our true spirit rises" (2000:125). Pollock introduces performative writing as a way for "writing/textuality speak to, of, and through...pain" (1998:79). It is from un lugar negro where I endeavor to perform memories arising from past patriarchal abuses. It is from un lugar negro where my newfound strength resides. This paper serves both as a personal cathartic performance and a empirical point of departure towards a yearning for building models of collective healing among

\footnotetext{
${ }^{1}$ Angie Mejia, MA, is a doctoral student in the department of Sociology at Syracuse University. Her research interests include issues of mental health in minority women and the use of participatory action research with U.S. Latino communities. She spends her time collecting shell cameos, playing video games with her husband and son, and mentoring college-aged Latina students. Address correspondence to: Angie Mejia, Syracuse University, 302 Maxwell Hall, Syracuse, NY 13244-1090; e-mail: amejia@syr.edu.
} 